\title{
Low temperature circulating fluidized bed gasification and co-gasification of municipal sewage sludge. Part 1: Process performance and gas product characterization
}

Thomsen, Tobias Pape; Sárossy, Zsuzsa ; Gøbel, Benny; Stoholm, Peder; Ahrenfeldt, Jesper; Jappe Frandsen, Flemming; Henriksen, Ulrik Birk

Published in:

Waste Management

Link to article, DOI:

10.1016/j.wasman.2017.04.028

Publication date:

2017

Document Version

Peer reviewed version

Link back to DTU Orbit

Citation (APA):

Thomsen, T. P., Sárossy, Z., Gøbel, B., Stoholm, P., Ahrenfeldt, J., Jappe Frandsen, F., \& Henriksen, U. B. (2017). Low temperature circulating fluidized bed gasification and co-gasification of municipal sewage sludge. Part 1: Process performance and gas product characterization. Waste Management, 66, 123-133. https://doi.org/10.1016/j.wasman.2017.04.028

\section{General rights}

Copyright and moral rights for the publications made accessible in the public portal are retained by the authors and/or other copyright owners and it is a condition of accessing publications that users recognise and abide by the legal requirements associated with these rights.

- Users may download and print one copy of any publication from the public portal for the purpose of private study or research.

- You may not further distribute the material or use it for any profit-making activity or commercial gain

- You may freely distribute the URL identifying the publication in the public portal 


\title{
1 Low Temperature Circulating Fluidized Bed gasification and co-gasification of
}

2 Municipal Sewage Sludge. Part 1: Process performance and gas product

3 characterization

\author{
4 Tobias Pape Thomsen ${ }^{a}$, Zsuzsa Sárossy ${ }^{a}$, Benny Gøbel ${ }^{b}$, Peder Stoholm ${ }^{c}$, Jesper Ahrenfeldt ${ }^{a}$, Flemming Jappe \\ 5 Frandsen $^{a}$, Ulrik Birk Henriksen ${ }^{a}$ \\ $6{ }^{a}$ Technical University of Denmark, Department of Chemical Engineering, DTU Risø Campus, Building 313, Frederiksborgvej 399, 4000 Roskilde, Denmark \\ $7 \quad{ }^{b}$ DONG Energy Thermal Power A/S, Nesa Allé 1, 2820 Gentofte, Denmark \\ $8{ }^{c}$ Danish Fluid Bed Technology ApS, Industrivej 38 C, 4000 Roskilde, Denmark
}

9 Abstract

The study is part 1 of 2 that investigates gasification of municipal sewage sludge (MSS) as well as co-gasification of MSS and cereal straw in low temperature gasifiers. Results from five experimental campaigns with Low Temperature Circulating Fluidized Bed (LT-CFB) gasification of straw and/or MSS from three different Danish municipal waste water treatment plants in pilot and demonstration scale are analyzed and compared. The gasification process is characterized with respect to process stability, process performance and gas product characteristics.

A total of $8600 \mathrm{~kg}$ of MSS dry matter was gasified during 133 hours of LT-CFB operation test with MSS fuels. The short term stability of all campaigns was excellent. LT-CFB gasification of dry MSS lead to substantial accumulation of coarse and rigid, but un-sintered, ash particles in the system, and these particles may negatively affect long term operation due to problems with decreased fluidization and circulation. Cogasification of MSS with sufficient amounts of cereal straw was found to be an effective way to mitigate these issues by substantially reducing the potential accumultion of oversize MSS ash particles and thereby also reducing the need for other means to control the bed composition. Characterization of gas products and process performance showed that even though gas composition varied substantially, hot gas efficiencies of around $90 \%$ could be achieved for all MSS fuel types.

Keywords: Municipal sewage sludge; cereal straw; thermal gasification; process performance; gas product characterization

\section{Introduction}

Modern techniques for cleaning municipal wastewater lead inevitably to production of municipal sewage sludge (MSS). The annual production of MSS in Europe, North America and Japan amounts to around 30 million ton dry matter, while the annual global production has been estimated to be around 50 million ton dry matter (Krüger and Adam, 2015; Zsirai, 2011). The global MSS production is increasing rapidly, driven by improved wastewater cleaning techniques, a growing global population, increasing wealth in developing parts of the world, and more strict regulations on emissions from wastewater treatment to the environment (Kelessidis and Stasinakis, 2012; Samolada and Zabaniotou, 2014). To avoid problems with pathogens, xenobiotics and toxins, greenhouse gases and foul odor, the produced sewage sludge requires appropriate handling. The benefits of 
thermal MSS management systems can include; i) energy recovery, ii) mass- and volume reduction, iii) odor reduction, iv) sterilization and purification by destruction of pathogens and organic xenobiotics (microplastics, pharmaceuticals, phthalates, flame retardants etc.), and, v) a general reduction of product variations and associated risks, providing increased robustness of the disposal system (Donatello and Cheeseman, 2013; Fytili and Zabaniotou, 2008; Samolada and Zabaniotou, 2014). Thermal gasification is one of the emerging thermal MSS management alternatives. The process has the same general advantages as other thermal processes plus some additional desirable qualities including: i) A flexible energy product range with a potential for gaseous, liquid and solid energy products, ii) High electric efficiency, even in very small scale with gas engines or fuel cells (Ahrenfeldt et al., 2013; Thomsen et al., 2015), iii) Reduced emissions and/or exhaust gas cleaning costs in combustion systems when pretreating the gas prior to combustion (Jenkins, 2015; Kang et al., 2011; Samolada and Zabaniotou, 2014), iv) Potential conservation and recycling of the critical nutrient phosphorous (P) and other valuable macro and micro nutrients in fertilizer ashes with high carbon content to increase security of supply, enhance soil quality and sequester carbon (Cordell and White, 2014; Hansen et al., 2016, 2015).

Several different thermal MSS gasification designs are currently under development including down-draft gasification (Arjharn et al., 2013), two-stage gasification (Mun et al., 2013; Mun and Kim, 2013), three-stage gasification (Choi et al., 2016), fluidized bed gasification (Calvo et al., 2013; Kang et al., 2011), Dual Fluidized Bed gasification (Xiaoxu et al., 2012) as well as fixed bed gasification (Werle, 2015) and fixed bed co-gasification of MSS and woody biomass (Ong et al., 2015; M. Seggiani et al., 2012). On a commercial or near-commercial level, the designs under development and testing include among others the SÜLZLE Kopf SynGas bubbling fluidized bed gasifier (Judex et al., 2012) and Outotec's dual-circulating fluidized bed gasifier (Buchholz, 2015).

There are several challenges related to efficient MSS management, and in systems with thermal gasification, these issues commonly relates to a very high content of moisture, ashes, and heavy metals combined with high heterogeneity and constant fluctuations in the MSS fuel characteristics as function of season and geography. The implications of these issues may be ash melting, bed agglomeration, low efficiency and/or substantial variations in the process performance and/or product composition and quality (Calvo et al., 2013; Krüger et al., 2014; Krüger and Adam, 2015; M. Seggiani et al., 2012; Maurizia Seggiani et al., 2012).

In this study it is hypothesized that co-gasification of MSS with straw in low temperature gasifiers with downstream gas combustion in CHP boilers may be an efficient way to mitigate some of the common issues related to MSS gasification. Mixing MSS and straw may reduce the practical impact of high ash content and heavy metal content in the MSS. In addition, mixing dewatered MSS and dry straw may reduce or eliminate MSS drying requirements. Finally, a proper mixture of MSS and straw may reduce fluctuations in fuel characteristics and process performance and product quality, and increase the fertilizer value of the ashes from the process by improving the phosphorus-potassium nutrient relationship and positively modify P plant availability. A low temperature process will make it possible to convert high alkali straw in fluidized bed systems, and direct downstream combustion of the gas product in existing medium to large CHP boilers may provide a more optimal combination of energy efficiency, emissions and economy. Such a system could prove to be a very interesting MSS management alternative in Denmark and other countries with similar resources of herbaceous biomass. 
Five experimental campaigns with cereal straw gasification, MSS gasification and MSS/cereal straw cogasification in two Low-Temperature Circulating Fluidized Bed (LT-CFB) gasifiers of very different scale are analyzed and compared in this work. The study is divided into two parts:

- Part 1: Process performance, product distribution and gas product characteristics (this study)

- Part 2: Ash product characteristics (composition, $\mathrm{pH}$ and $\mathrm{P}$ fertilizer quality) and estimation of elemental balances for selected elements and heavy metals (Thomsen et al., 2017)

\section{Materials and Method}

\subsection{About the LT-CFB gasifier}

The LT-CFB process was selected for the investigation as it is a very fuel flexible platform that has been proven to operate on many different fuels including cereal straw, biogas- and manure fibers and organic residues from industry. Schematics of the process are provided in Figure 1, and a more details on the LT-CFB process design and previous operational results can be found in literature (Ahrenfeldt et al., 2013; Kuligowski et al., 2008; Narayan et al., 2016; Nielsen, 2007; Stoholm et al., 2008).

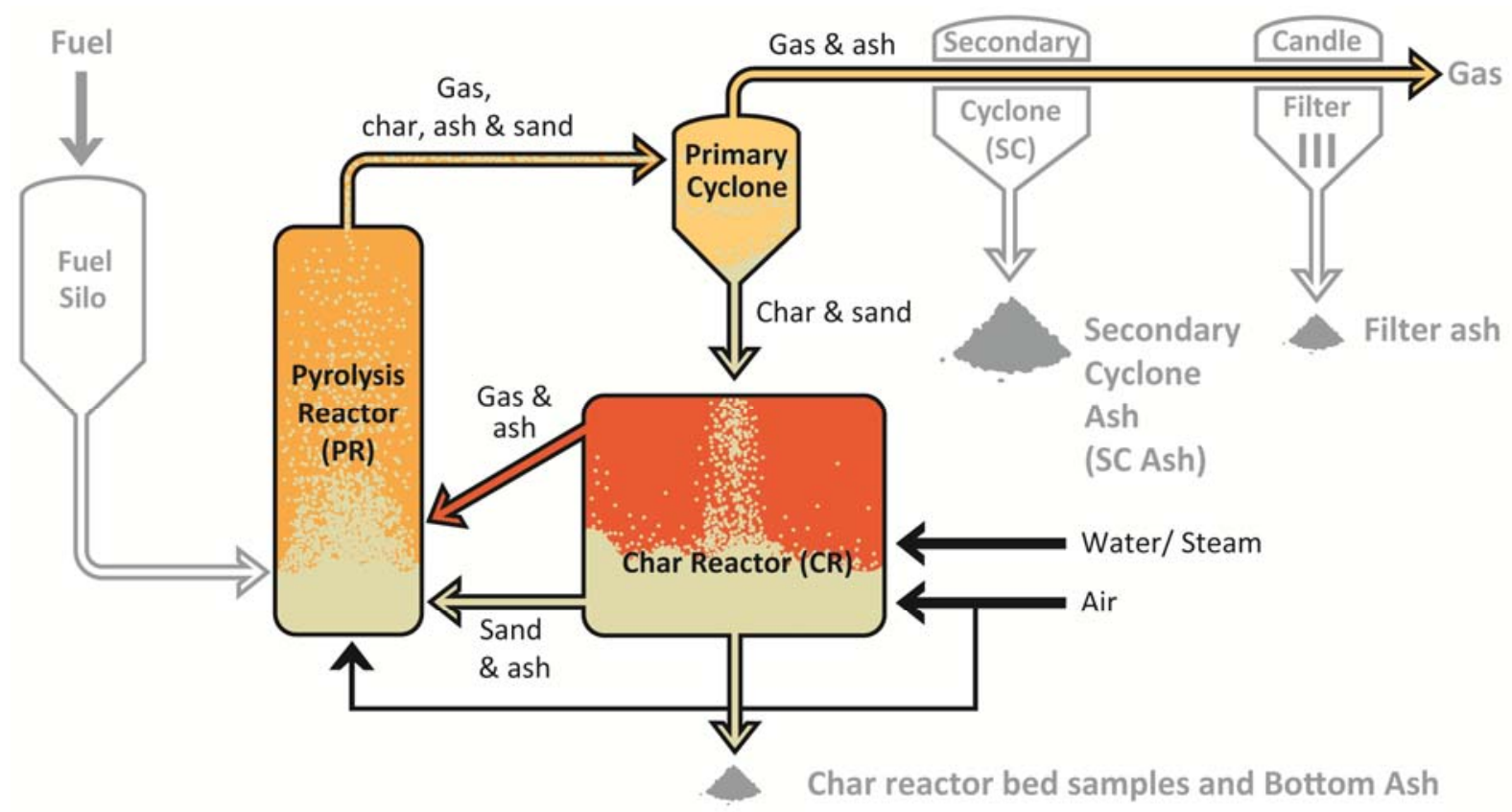

Figure 1: Low Temperature Circulating Fluidized Bed (LT-CFB) gasification system. Modified from (Thomsen et al., 2015).

The LT-CFB technology has been under development for almost 20 years and has been bought and commercialized by DONG Energy under the alias Pyroneer in recent years. The largest LT-CFB built has a thermal capacity (TH) of $6 \mathrm{MW}$ and is located at Asnaes Power Plant in Kalundborg, Denmark. When operating, the $6 \mathrm{MW}$ unit supplies product gas to a suspension-fired coal boiler, thereby substituting coal in a high efficiency CHP system (DONG Energy Power A/S, 2012). In addition to the $6 \mathrm{MW}_{T H}$ unit, a $100 \mathrm{~kW}_{\text {TH }}$ pilot scale 
LT-CFB unit exist at the Technical University of Denmark (DTU) at Campus Ris $\varnothing$ near Roskilde. The $100 \mathrm{~kW}$ unit has an option for hot gas filtration in a candle filter. The present study includes data from campaigns conducted at both of these LT-CFBs using quartz sand without additives as bed material (DanSand.dk, 2013).

\subsection{About the campaigns and fuels}

Results from five campaigns are included in the present study. Two of the campaigns were conducted on dry MSS granules, two were conducted on mixes of dry or dewatered MSS and dry Danish wheat straw, and one was conducted on dry Danish wheat straw alone. The MSS fuel campaigns ranged between 17 and 40 hours of operation, and the MSS consumption varied between 45 and $7500 \mathrm{~kg}$ MSS dry matter. A brief description of the campaigns is provided in Table 1. A hot gas candle filter made from inorganically bonded granular minerals (TENMAT FIREFLY, Manchester, UK) was applied in two of the campaigns to further clean the product gas of particulate material. Four MSS samples have been gasified during the five campaigns. The MSS samples originate from three different Danish wastewater treatment plants (WWTPs) in Randers (Randers WWTP), Aabenraa (Stegholt WWTP), and, Roskilde (Bjergmarken WWTP). The WWTPs are described in detail in part two of the study (Thomsen et al., 2017). Proximate analysis data on the five test fuels are provided in Table 2.

Table 1: Overview of Low Temperature Circulating Fluid Bed (LT-CFB) campaigns. ST: Stegholt WWTP. BJ: Bjergmarken WWTP. RA: Randers WWTP. WWTP: Wastewater treatment plant. Th: Thermal capacity. MSS: Municipal sewage sludge

\begin{tabular}{cccc}
\hline Name & Fuel type & LT-CFB plant & Filter \\
\hline REF & Crushed wheat straw pellets & Ris $\varnothing$ DTU, 100 kW & Th \\
MIX-ST & Mix: Dewatered MSS (ST) + crushed straw pellets & Ris $\varnothing$ DTU, 100 $\mathrm{kW}_{\text {Th }}$ & No \\
MIX-BJ & Mix: Dry MSS pellets (BJ) + straw pellets & Asnaes Power plant, 6 MW & Nh \\
SLU-BJ & Dry MSS granules (BJ) & Ris $\varnothing$ DTU, 100 $\mathrm{kW}_{\text {Th }}$ & Yes \\
SLU-RA & Dry MSS granules (RA) & Ris $\varnothing$ DTU, 100 $\mathrm{kW}_{\text {Th }}$ & No \\
\hline
\end{tabular}

Table 2: Fuel characterization. DM: Dry Matter. D.a.f: Dry, ash free.

\begin{tabular}{|c|c|c|c|c|c|c|}
\hline & & Reference & $\mathrm{MIX}-\mathrm{ST}^{1}$ & $M \mid X-B J^{1}$ & SLU-BJ & SLU-RA \\
\hline \multirow{2}{*}{$\begin{array}{l}\text { MSS:Dry } \\
\text { straw mixing } \\
\text { ratio }\end{array}$} & $\%$ wet & $0: 100$ & $30: 70$ & $21: 79$ & 100:0 & 100:0 \\
\hline & \% DM & $0: 100$ & 11:89 & $14: 86$ & 100:0 & 100:0 \\
\hline Moisture & $\%$ wet & 10.6 & 29.9 & 12.5 & 12.5 & 4.6 \\
\hline Volatiles & $\% \mathrm{DM}$ & 68.4 & 67.7 & 66.5 & 42.7 & 43.1 \\
\hline Fixed carbon & $\% \mathrm{DM}$ & 23.8 & 22.5 & 20.1 & 14.2 & 15.2 \\
\hline Ash & $\% \mathrm{DM}$ & 7.9 & 9.8 & 13.3 & 43.1 & 43.8 \\
\hline HHV, wet & $\mathrm{MJ} / \mathrm{kg}$ & 16.1 & 13.2 & 14.8 & 11.4 & 12.2 \\
\hline HHV, d.a.f & $\mathrm{MJ} / \mathrm{kg}$ & 19.6 & 20.9 & 19.5 & 22.9 & 22.0 \\
\hline
\end{tabular}


113 Proximate compositions of fuels were determined as follows: Moisture content (ASTM D3173-73, DS/EN 114 14774-3 (2009) and EN 12880), Volatile matter: ASTM D3175-73 and Ash content: (ASTM D3174-73, DS/EN 11514775 (2009) and EN 15169 (2007)).

116 Fuel and ash higher heating values were determined by bomb calorimetry on a Parr 6300 Bomb Calorimeter 117 (Parr Instrument Company, Moline, Illinois, USA). In samples with very low heating values, a mixture of solid 118 benzoic acid ( $26.454 \mathrm{MJ} / \mathrm{kg} \mathrm{HHV}$ ) and ash (50/50\% by weight) was prepared and combusted in the bomb 119 calorimeter.

120 All data from operation of the $100 \mathrm{~kW}$ plant (fuel feeding rate, system temperatures, system pressures, SC ash 121 production rate, air flows, nitrogen flows and water/steam flows) was logged using National Instruments 122 Labview 2015 software. Data from the $6 \mathrm{MW}$ plant was provided by DONG Energy A/S, Denmark using a process control and data acquisition system from 2012 developed and implemented by SIEMENS, Germany. Analysis of product gas from the $100 \mathrm{~kW}$ unit, was performed with an Advance Optima 2020 Modular continuous process gas analyzer system, applying a Caldos 15 cell for $\mathrm{H}_{2}$ analysis and an Uras 14 cell for $\mathrm{CO}$, $\mathrm{CO}_{2}$, and $\mathrm{CH}_{4}\left(\mathrm{ABB}\right.$, Switzerland). Content of $\mathrm{O}_{2}$ was determined using a PMA $10 \mathrm{O}_{2}$-Analyser. Prior to analysis gas was cleaned in a system composed of a bobble flask with tap water and two serial twist-filters before conditioning in a CSS-V Sampling-system (M\&C TechGroup, Germany). Heating Values of the cold gas products were calculated using calorific values for the included gas components representative at $25^{\circ} \mathrm{C}$ and $1 \mathrm{~atm}$ (Turns, 2012).

Gas sampling for simple hydrocarbon was performed using conservatively flushed gas pipettes. Three samples were extracted from the product gas before the gas analyzer. The samples were analyzed for simple hydrocarbons using a GC system with flame ionization detection (FID) and GC-MS. A series of 10 simple hydrocarbons from ethane up until benzene were measured using this system.

Quantification of the tar and water content in the product gas was done using a simple method developed at DTU Chemical Engineering. The method combines cooling and condensation with gas volume determination and calorimetry. The experimental setup is illustrated in Figure 2. All the applied equipment (Figure 2) was cleaned and weighted before and after the experiment. The time of the experiment was recorded and the total non-condensing gas volume measured by the gas meter. Total condensate was quantified and divided into two main fractions i.e. light and heavy, and the tar-water ratio of the two fractions determined by calorimetry using a Parr 6300 Bomb Calorimeter with paraffin coated ignition threads. A dry tar HHV of $27 \mathrm{MJ} / \mathrm{kg}$ was assumed based on previous experience with LT-CFB tar and published literature on the heating value of the oil phase collected from MSS pyrolysis (Fonts et al., 2012). GC was used to verify that tar composition in the two 


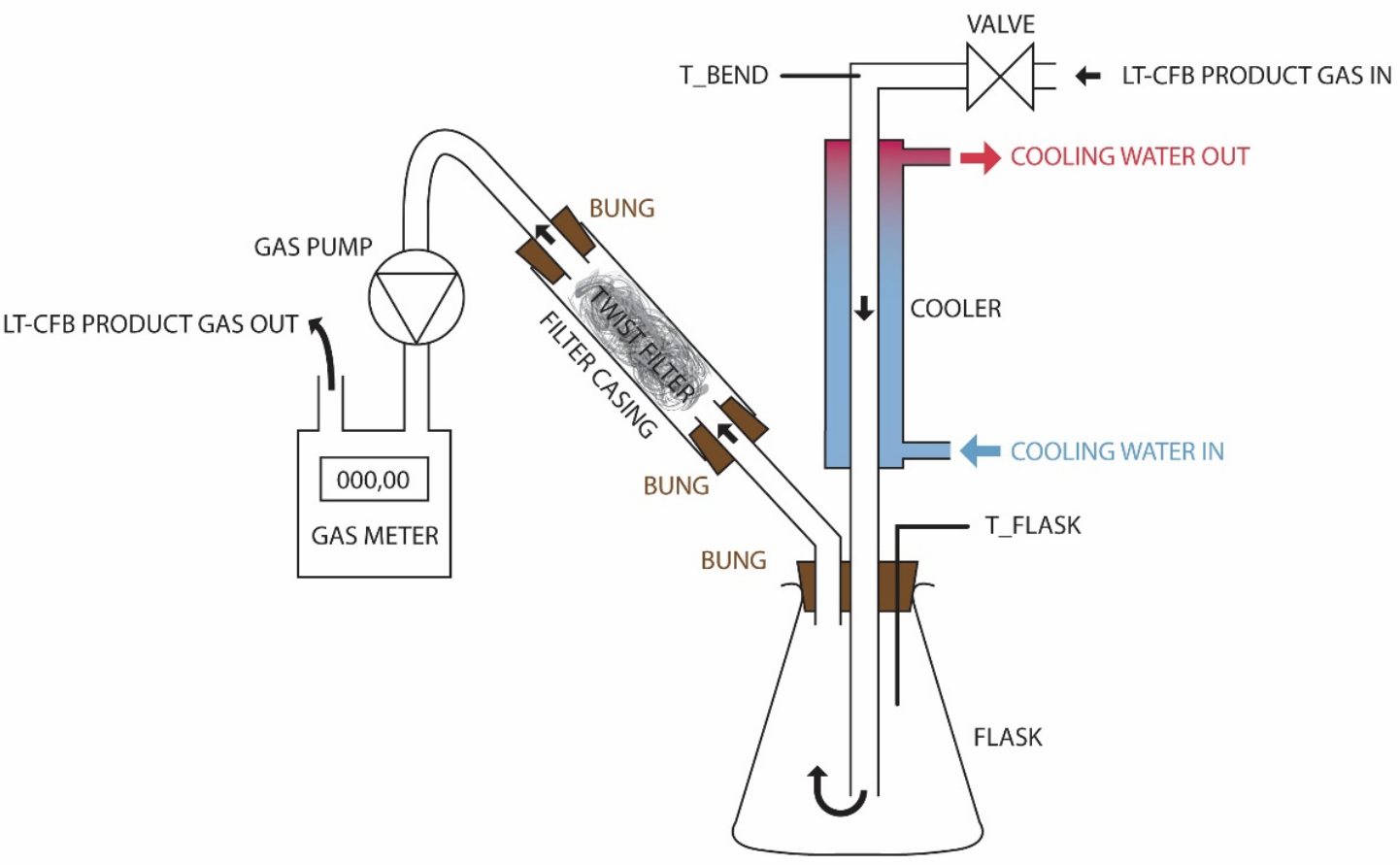

Figure 2: Experimental setup for quantification of total tar and water in gasification product gas. LT-CFB: Low temperature circulating fluidized bed gasifier. T: Temperature measurement point.

Tar collection for characterization and gravimetric tar measurements was done by bubbling product gas through acetone in a Petersen column (Grosch et al., 2015). The acetone was transferred to a measurement flask, and the weight difference between the clean flask and the same flask with dry tar residues after evaporation and thermal drying of the content was calculated and considered as total gravimetric tar. The analysis was done in duplicate.

Determination of phenolics was performed on a mixture of the acetone sample and deuterated phenol (phenol d5) solution. Samples were extracted with cyclohexane after $\mathrm{pH}$ increase and the cyclohexane phase discharged with diethyl-ether. The sample was extracted again with diethyl-ether after lowering $\mathrm{pH}$ and the ether phase was collected and traces of water removed. The samples were analyzed with a Hewlett Packard HP 6890 gas chromatograph interfaced to a HP5973 Mass Selective Detector with a HP 7683 autosampler (Agilent, Denmark). Product separation was done using a 0.32-mm i.d. $\times 30 \mathrm{~m}$ WCOT-fused silica column coated with VF$23 \mathrm{~ms}$ at a thickness of $0.25 \mu \mathrm{m}$ (Analytical, Denmark). Quantification was performed using the instrument responses and the known amount of deuterium labeled added standards.

Determination of polycyclic aromatic hydrocarbons (PAH) was performed on a mixture of the collected acetone sample and a standard solution with deuterated naphthalene, acenaphtene, fluorene, phenantrene, anthracene, fluoranthene and pyrene. Cyclohexane was added to the mixture and after mixing, $2 \mathrm{M} \mathrm{NaOH}$ solution was added. The cyclohexane phase was separated and traces of water were removed by adding $\mathrm{Na}_{2} \mathrm{SO}_{4}$. The samples were then analyzed using GC-MS as described above. The products were separated using 

Denmark). PAH compounds were identified using the NIST search engine version $2.0 \mathrm{f}$. (Agilent, Denmark).

Content of total $\mathrm{N}$ and ammonia was measured in the condensable fraction of the product gas by bubbling part of the hot product gas through three impinger bottles in series containing demineralized water. The bottles were cooled in ice bath and all condensable compounds were extracted from the gas. The concentrations of ammonium $\left(\mathrm{NH}_{4}{ }^{+}\right)$and nitrate $\left(\mathrm{NO}_{3}{ }^{-}\right)$as well as total dissolved $\mathrm{N}$ (TDN) were analyzed by standard colorimetric procedures on an AutoAnalyzer 3 (Bran+Luebbe, Norderstedt, Germany). The completeness of the condensation was determined by comparing the concentrations in the three flasks.

Simple mass and energy balances were performed using data on relevant process inputs (Fuel (mass and HHV), fresh bed material (mass), total air supply (mass) and total water supply (mass)) and process outputs (SC ash (mass and HHV), Filter ash (mass and HHV), Char reactor bed draining (mass and HHV), final bed composition (mass and HHV)). Total gas product mass was estimated by balance. Subsequently, the total mass of the gas product was divided into tar, steam and dry, tar-free gas using the results from the tar and water quantification. The Higher Heating Value of dry tar was assumed to be $27 \mathrm{MJ} \mathrm{kg}^{-1}$ (Fonts et al., 2012), and the specific heat capacity of $\operatorname{tar} 1.47 \mathrm{~kJ} \mathrm{~kg}^{-1} \mathrm{~K}^{-1}$ at $500-600{ }^{\circ} \mathrm{C}$ (Engineeringtoolbox.com, 2016a). The specific heat capacity of the dry, tar-free gas was assumed described by the content and heat capacity of $\mathrm{N}_{2}$ and $\mathrm{CO}_{2}$ alone (1.11-1.12 and 1.15-1.20 $\mathrm{kJ} \mathrm{kg}^{-1} \mathrm{~K}^{-1}$ respectively at 500-600 ${ }^{\circ} \mathrm{C}$ (Engineeringtoolbox.com, 2016b, 2016c)). Finally, the specific heat capacity of steam at $500-600{ }^{\circ} \mathrm{C}$ was assumed to be $2.11-2.18 \mathrm{~kJ} \mathrm{~kg}^{-1} \mathrm{~K}^{-1}$

(Engineeringtoolbox.com, 2016d) and the enthalpy of evaporation of the water to be $2.30 \mathrm{MJ} \mathrm{kg}^{-1}$ (Chang and College, 2002). Air, water and fuel were assumed to have a temperature of $25^{\circ} \mathrm{C}$ before entering the system. The potential evaporation of inorganics is estimated based on laboratory study approximations (Thomsen et al., 2015). This approach was chosen because a fully satisfactory energy balance based on enthalpy was not possible to establish due to the complexity of the hot product gas.

\section{Results and discussion}

\subsection{Fuel feeding and thermal loads}

A total of $8600 \mathrm{~kg}$ MSS dry matter was gasified during a total of 133 hours of operation distributed with $45 \mathrm{~kg}$ in 28 hours in the MIX-ST campaign, $7500 \mathrm{~kg}$ in 48 hours in the MIX-BJ campaign, $240 \mathrm{~kg}$ in 17 hours in the SLU-BJ campaign and $800 \mathrm{~kg}$ in 40 hours in the SLU-RA campaign. The feeding systems worked well for all fuel types. Based on the fuel heating value and the fuel feeding rate, the fuel input thermal load of the LT-CFB gasifiers during the different campaigns has been estimated. These results are provided on basis of HHV in Table 3 .

In general, a higher thermal load was achieved in the straw campaign (REF) and the co-gasification campaigns (MIX-ST \& MIX-BJ) than in the MSS-only campaigns (Table 3). Extensive experiences with operation on straw as well as a system designed for this purpose is part of the reason behind this difference. Also, the higher heating value of the straw-based fuels led to higher thermal loads at comparable mass based feeding rates. Finally, the 
lower ash content in the straw and straw-MSS mix required less effort to maintain a stable system mass and gave fewer restrictions on the feeding rate in regard to potential mass accumulation in the system. Heating Value of fuels.

\begin{tabular}{lccc}
\hline & $\begin{array}{c}\text { Nominal thermal capacity } \\
\mathrm{kW}_{\text {TH }}\end{array}$ & $\begin{array}{c}\text { Average thermal load } \\
\mathrm{kW}_{\mathrm{TH}}\end{array}$ & $\begin{array}{c}\text { Peak thermal load } \\
\mathrm{kW}_{\mathrm{TH}}\end{array}$ \\
\hline REF & 100 & 88 & 99 \\
MIX-ST & 100 & 77 & 95 \\
MIX-BJ & 6000 & 6158 & N.A \\
SLU-BJ & 100 & 62 & 73 \\
SLU-RA & 100 & 71 & 81 \\
\hline
\end{tabular}

All tested MSS fuels gave good preliminary operational results. However, efficient LT-CFB gasification requires a relatively dry fuel or fuel mix with a maximum of 25-30 wt\% moisture (Ahrenfeldt et al., 2013). The feasible range of MSS-straw mixing ratios that can be converted in LT-CFB gasifiers is thereby limited by the moisture content of both the MSS and the straw.

\subsection{Product distribution}

Mass based product distribution results are provided in Figure 3.

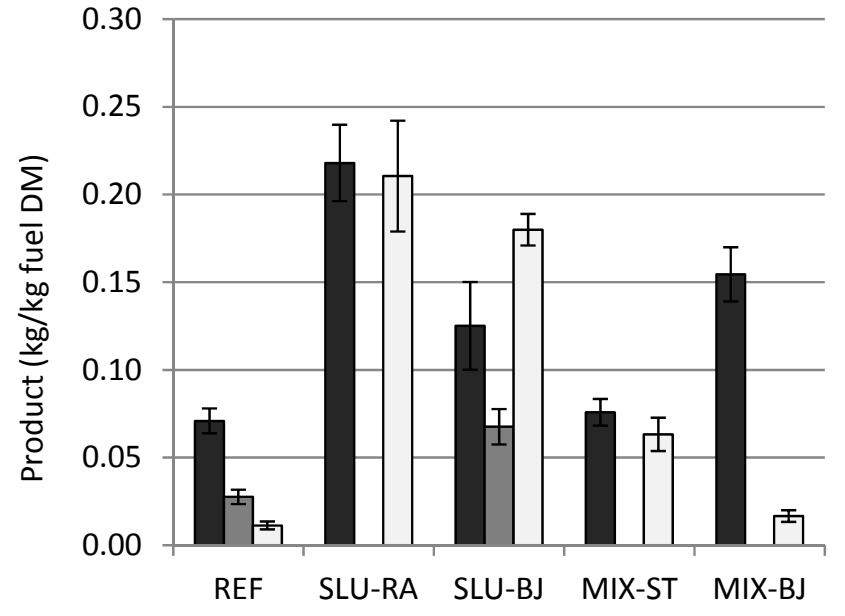

SC ash $\square$ Filter ash* $\square$ Accumulated + drained CR bed

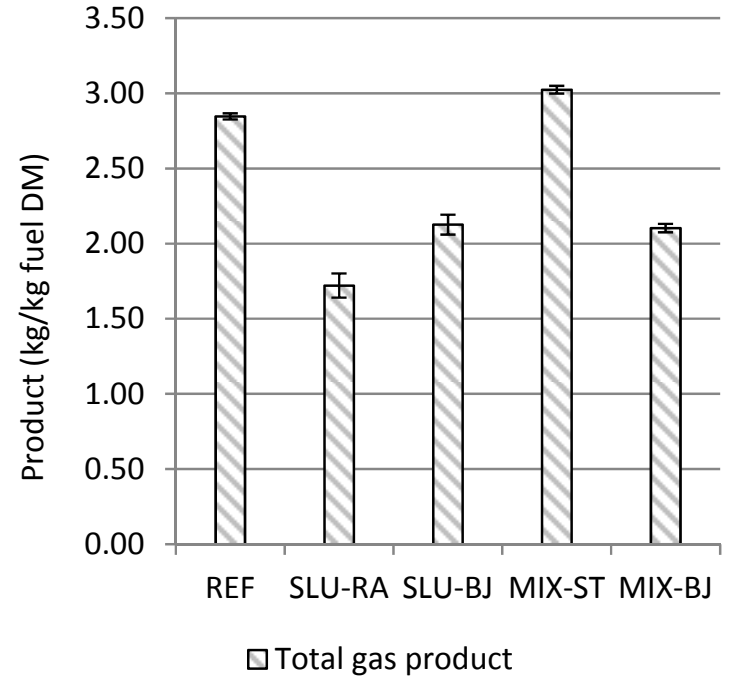

Figure 3: Mass distribution of products in the assessed low temperature gasification campaigns. Results on basis of dry fuel feed. Accumulated + drained CR bed: Sum of fuel mass accumulated in the bed or drained as bottom ashes from the Char Reactor (CR). SC: Secondary Cyclone. * Filter ash only collected in REF and SLU-BJ campaigns. 
Variations in total mass of gas product are due to differences in supply of air and water among the campaigns, combined with differences in fuel ash and moisture content. There are also characteristic differences among the production of SC ash, and the sum of bed material, accumulating and drained as bottom ashes. Both of 220 these product fractions increase severely, when operating on sludge only as a consequence of the very high ash 221 content in the dry sludge fuels (Table 2).

\section{$222 \quad 3.3 \quad$ Process stability}

\section{$223 \quad 3.3 .1 \quad$ Temperatures and pressures}

224 The temperatures recorded in the char reactor (see Figure 1 ) were very stable with maximum temperatures of $225735-750^{\circ} \mathrm{C}$ across all campaigns. The temperature fluctuations in the char reactor were generally smaller in 226 straw and straw/MSS campaigns $\left(10-15^{\circ} \mathrm{C}\right)$ than in the MSS-only campaigns $\left(35-40{ }^{\circ} \mathrm{C}\right)$ whereas the temperature fluctuations in the pyrolysis reactor was comparable in the REF and SLU campaigns $\left(20-30^{\circ} \mathrm{C}\right)$ and substantially higher in the MIX-ST campaign $\left(50^{\circ} \mathrm{C}\right)$. The vertical temperature gradients in the char reactor bed was just $5-10{ }^{\circ} \mathrm{C}$ in all campaigns while the temperature difference between the bed and the freeboard ranged from $20-50{ }^{\circ} \mathrm{C}$ in the SLU campaigns to $60^{\circ} \mathrm{C}$ in the REF campaign and almost $80^{\circ} \mathrm{C}$ in the MIX-ST campaign. The vertical temperature gradients in the pyrolysis reactor was generally the same in all campaigns $\left(10-20^{\circ} \mathrm{C}\right.$ difference from top to bottom) except for the MIX-ST campaign where it was at least 5 times as high (around $100^{\circ} \mathrm{C}$ ) due primarily to the cooling effect of the water in the fuel. Similarly, there was a noticeably larger difference between the average temperatures in the char reactor and pyrolysis reactor in the MIX-ST campaign $\left(160^{\circ} \mathrm{C}\right)$ than in the other campaigns $\left(25-50^{\circ} \mathrm{C}\right)$ owing mainly to higher water content in the MIX-ST fuel. Towards the end of the two SLU campaigns the temperature difference between the char and pyrolysis reactors started to increase continuously indicating reduced circulation of bed mass. The development in the SLU-BJ temperatures and the difference towards the MIX-ST temperatures are illustrated in Figure 4 with data from 10 aggregated periods of 30-60 minutes covering the full campaign periods.
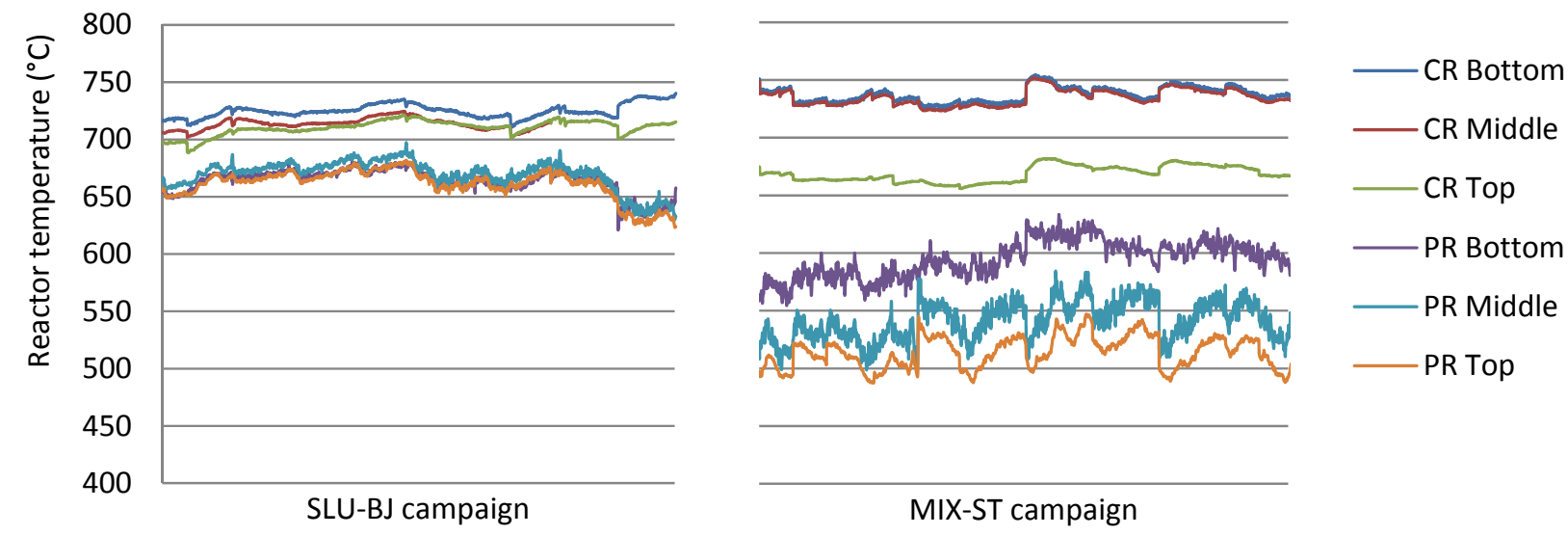

Figure 4: Pyrolysis reactor (PR) and char reactor (CR) data curves from SLU-BJ campaign (left) and MIX-ST campaign (right). Data aggregated from 10 periods of 30-60 minutes totaling 8 hours out of a total operation data set of 17 hours (SLU-BJ campaign) and 28 hours (MIX-ST campaign). 
The reduced circulation at the end of the SLU campaigns was accompanied by development in the system pressures. In general these were quite stable in all campaigns with high pressure drops across the bed in the char reactor as well as pyrolysis reactor, indicating full fluidization. However, there was a continuously decreasing pressure difference across the char reactor in the last part of the two SLU campaigns, which was not observed in the REF and MIX campaigns. Declining pressure drop indicates declining bed mass and density and/or incompleate fluidization, which can be due to increasing bed particle sizes (Kunii and Levenspiel, 1991). The development (example in Figure 5) follows the increased temperature differences between the reactors and in combination this also indicates reduced circulation. This development is only evident in the MSS-only campaigns, and therefore co-gasification MSS with straw in proper mixing ratios seem to be a simple and efficient way to mitigate this issue and avoid the need for other bed particle management efforts.
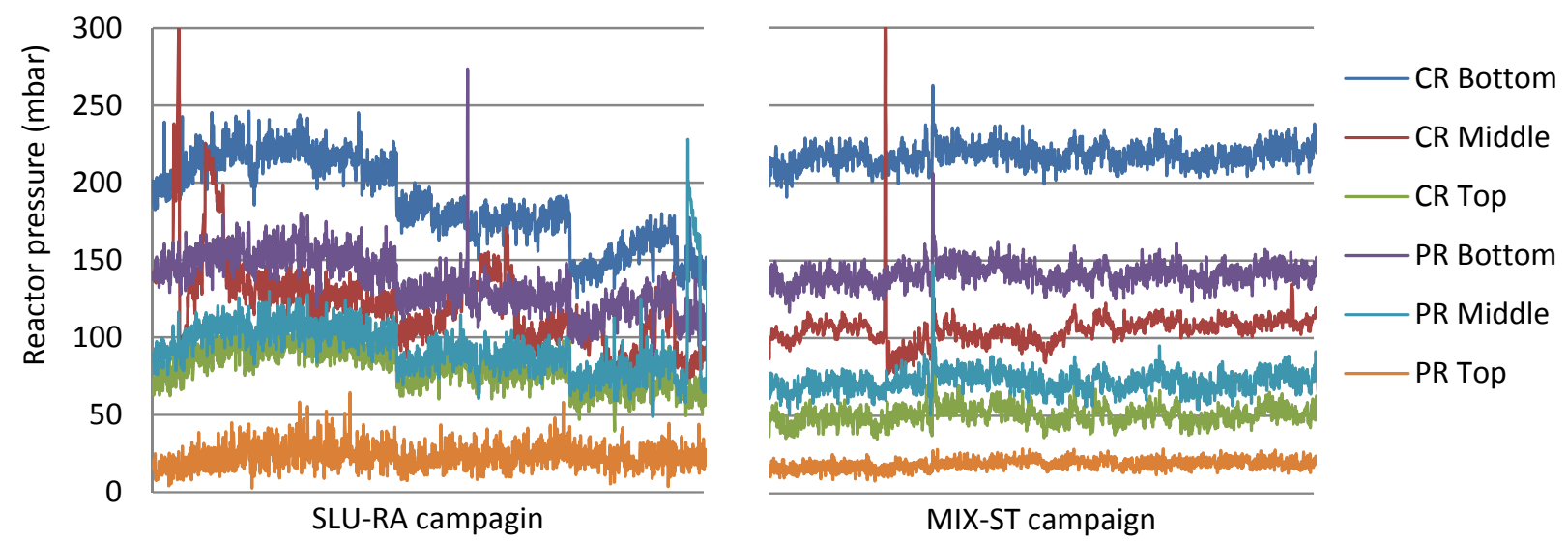

Figure 5: Pyrolysis reactor (PR) and char reactor (CR) pressure curves from SLU-RA campaign (left) and MIX-ST campaign (right). Data aggregated from 10 periods of 30-60 minutes totaling 8 hours out of a total operation data set of 40 hours (SLU-RA campaign) and 28 hours (MIX-ST campaign).

\subsubsection{Stability of internal system mass and volume}

Stability of the system operation impels a somewhat stable internal mass and volume of particles.

Accumulation of mass is a common phenomenon in fluid bed systems, especially when using extremely ashrich fuels like MSS, which has also been observed in the study by Calvo et al. from 2013 (Calvo et al., 2013). The simplest way to counteract such accumulation is to drain out surplus bed material.

The potential influence of the MSS fuel composition on the rate of bed draining required to maintain a constant inorganic mass within the system has been estimated by simple inorganic mass balances of the five campaigns. The goal was to determine if there was significant correlation and if such a correlation was linear or non-linear. Results are provided in Figure 6. 


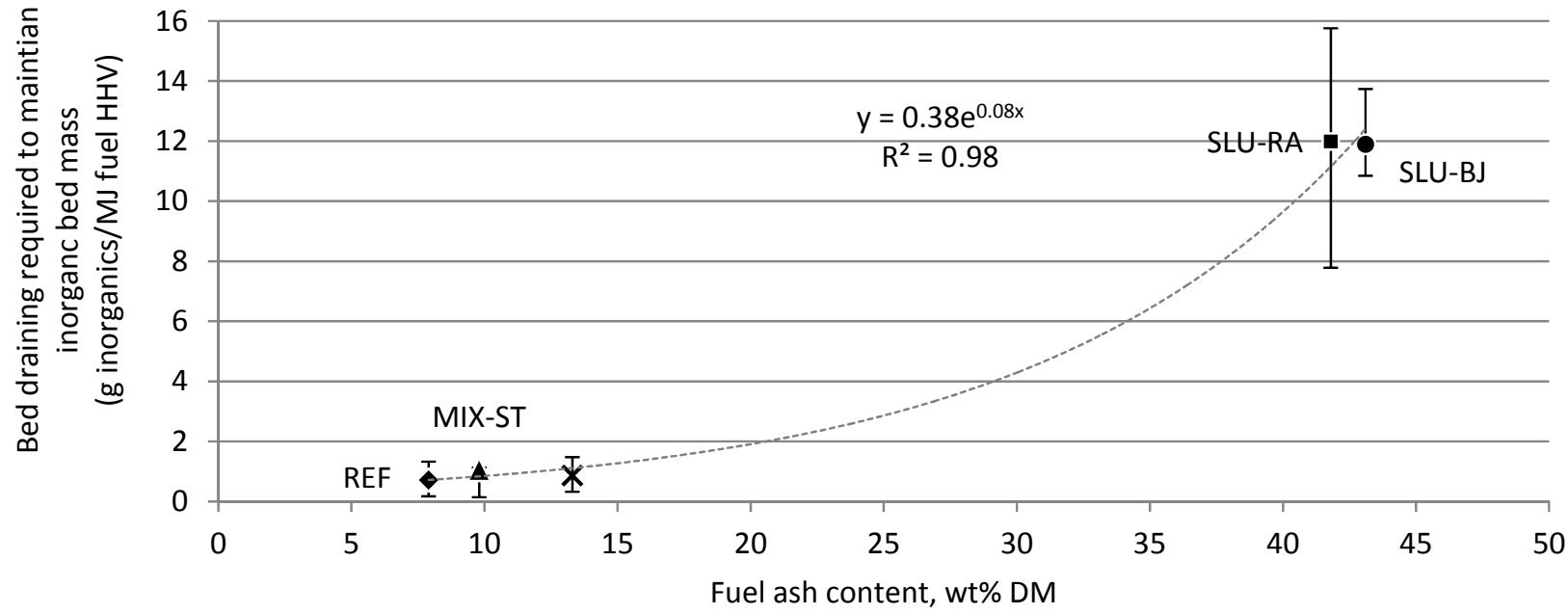

Figure 6: Rate of bed draining required to maintain a stable mass of inorganics in the bed as function of fuel ash content during five LT-CFB campaigns with different fuels. DM: Dry matter. HHV: Higher Heating Value.

Despite the uncertainties there is a strong trend in the results and a very significant difference between MSSonly campaigns on one side and straw and MSS/straw campaigns on the other (Figure 6). There is no significant difference between the potential accumulation of inorganics during the REF, MIX-ST and MIX-BJ campaigns, and also no significant difference between the two MSS-only campaigns. Part of the explanation behind this effect is obviously differences in absolute fuel ash input and perhaps especially absolute MSS ash input. Another important part of the explanation is that the reduced amount of ash in the co-firing system allows for longer retention time of the large ash particles in the system. A long retention time increase the degree of mechanical particle attrition thus also increasing the chance that relatively more small ash particles leave via the cyclones.

It should be notised, that during the reported test campaigns, the goal was not to keep a constant bed mass or volume but rather to keep the bed particle inventory within the limits allowing for sufficient particle circulation and consequently a proper temperature level in the pyrolysis reactor. Hence, bed draining requirements cannot be sufficiently analyzed by monitoring the total bed mass alone. Despite these reservations, the combined set of results from the five LT-CFB campaigns indicate substantial benefits of co-gasification of MSS and cereal straw with regard to stability of bed mass (Figure 6) and fluidization (Figure 4 and Figure 5).

\subsection{Gas quality and composition}

\subsubsection{Composition of dry, tar-free gas}

In each campaign, the dry, tar-free product gas composition has been recorded for periods of at least 1.5-3 hours. A summary is provided in Figure 7.

There are some significant differences in the gas composition and heating value, between the different fuel types (SLU $><\mathrm{MIX}><\mathrm{REF}$ ), and while the gas products from the two SLU campaigns are very comparable, there 
are profound differences among the MIX campaigns which is probably mainly due to the high moisture content in the MIX-ST fuel mix (Figure 7). Generally, the most significant differences are in the $\mathrm{H}_{2}(\approx 1-7 \mathrm{vol} \%)$ and $\mathrm{CO}$ content ( $\approx 4-11$ vol\%), and higher heating value $\left(2\right.$ to $\left.5 \mathrm{MJ} / \mathrm{Nm}^{3}\right)$ whereas the contents of $\mathrm{CH}_{4}(\approx 2-3$ vol\%) and $\mathrm{CO}_{2}(\approx 16-18 \mathrm{vol} \%)$ are more uniform among the campaigns. $\mathrm{O}_{2}$ content in all products is practically zero (data not shown). $\mathrm{N}_{2}$ is not quantified, but can be expected to constitute the vast majority of the composition balance. The content of simple hydrocarbons $\left(\mathrm{C}_{2-6} \mathrm{H}_{2-10}\right)$ in the REF campaign constituted 2.3 vol\% of the gas but almost $40 \%$ of the total energy potential in the dry, tar-free gas. As the content of simple hydrocarbons was not measured in the other gas products, the LHV and HHV results from these campaigns should be used with caution. The main $\mathrm{C}_{2-6} \mathrm{H}_{2-10}$ contributors in the REF gas products were ethylene (13\% of total HHV), propene (9\%), 2-butene (7\%), ethane (4\%) and cyclopentane (4\%). The content of simple hydrocarbons in product gas from MSS gasification has been investigated in three previously published studies, and was found to constitute from 0.1 to as much as 7 vol\% of the cold, dry gas (Choi et al., 2016; Mun et al., 2013; Roche et al., 2014). The influence of tar and simple hydrocarbons is expected to substantially influence the $\mathrm{H}_{2}$ concentration as varying amounts of hydrogen may be fixed in simple hydrocarbons and tars and thereby not identified as $\mathrm{H}_{2}$ in the cold, dry gas product.

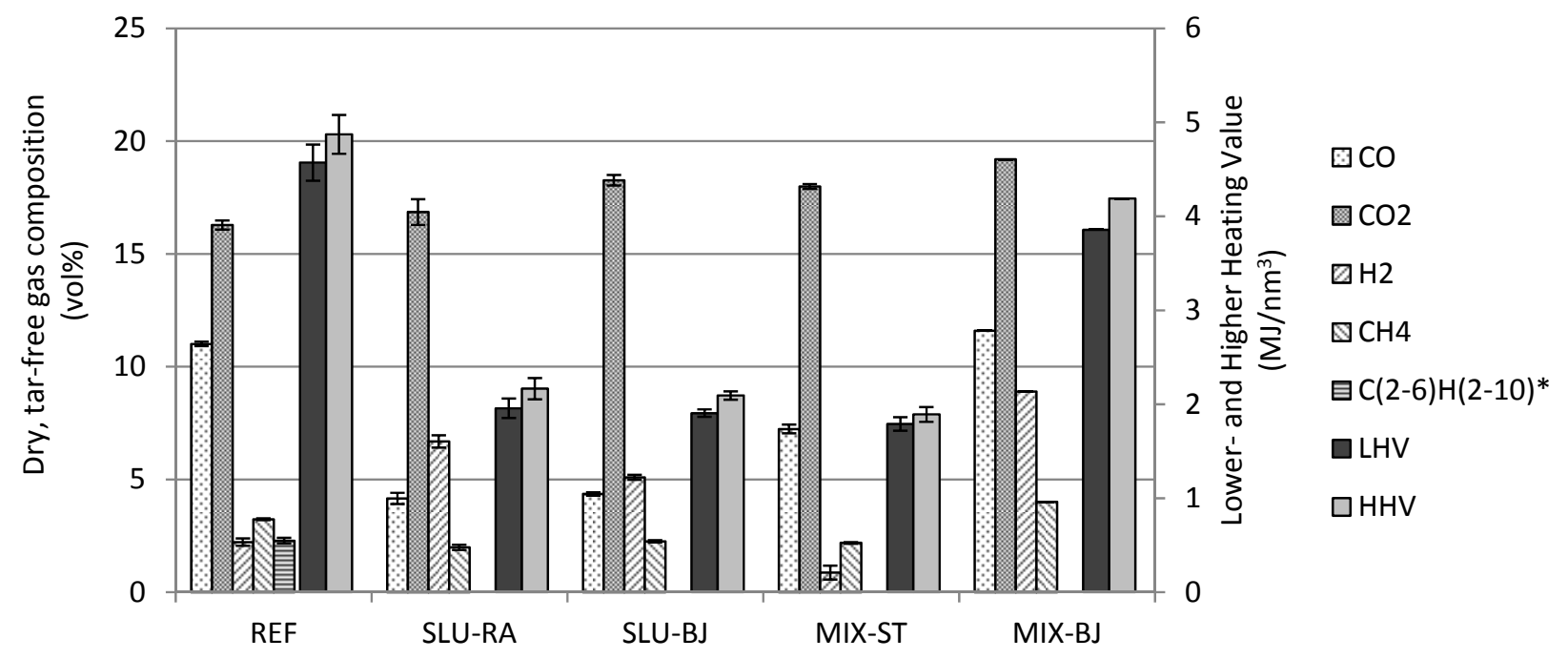

Figure 7: Composition of dry, tar-free product gas. $\mathrm{N}_{2}$ major balancing gas component. LHV: Lower Heating Value. HHV: Higher Heating Value. *: Content of simple hydrocarbons with compositions $\mathrm{C}_{2-6} \mathrm{H}_{4-10}$ has only been measured in the REF campaign.

\subsubsection{Tar quantification and characterization}

During the REF and SLU-BJ campaigns comparable amounts of gravimetric tars were collected, whereas the MIX-ST yielded 20-30 times as much gravimetric tar (Table $4 \mathrm{~A}$ ). The amount of tar collected is substantially higher than those reported in the published literature. Roche et al (2014) and Mun et al (2013) produced 3400$10000 \mathrm{mg} / \mathrm{Nm}^{3}$ and around $6000 \mathrm{mg} / \mathrm{Nm}^{3}$ respectively in lab scale fluidized bed gasifiers, converting sludge at temperatures around $800^{\circ} \mathrm{C}$ (Mun et al., 2013; Roche et al., 2014). The low pyrolysis temperature during the MIX-ST campaign is the main driver behind the large tar content in the product gas of this campaign as 
discussed below. Furthermore, there were several tar-reducing initiatives in the experimental setup in the previously published studies, while the LT-FCB product gas is untreated.

Table 4. A) Quantification of gravimetric tar, phenol and PAH contents in tar collected during the REF, MIX-ST and SLU-BJ campaigns using a Petersen column. B) Quantification of total tar, water and permanent gases in gas products from the REF and MIX-ST campaigns using condensation, calorimetry and gas volume measurements (Figure 2). PG: Product gas. N.A.: Not Analyzed.

\begin{tabular}{lcccc}
\hline & & REF & MIX-ST & SLU-BJ \\
\hline A) Gravimetric tar & $\mathrm{mg} / \mathrm{Nm}^{3} \mathrm{PG}$ & $33 \cdot 10^{3}$ & N.A. & $26 \cdot 10^{3}$ \\
Phenol content & $\mathrm{mg} / \mathrm{Nm}^{3} \mathrm{PG}$ & 883 & N.A. & 390 \\
PAH content & $\mathrm{mg} / \mathrm{Nm}^{3} \mathrm{PG}$ & 136 & N.A. & 226 \\
B) Total tar & wt\%, PG & $1 \pm 1$ & $12 \pm 2$ & N.A. \\
Water & wt\%, PG & $14 \pm 3$ & $24 \pm 2$ & N.A. \\
Permanent gases & wt\%, PG & $84 \pm 5$ & $64 \pm 2$ & N.A. \\
\hline
\end{tabular}

The results from quantification of total tar, water and permanent gases using an in-house method (Table 4 B) largely support the previously determined difference in the tar content of the two gas products from the REF and MIX-ST campaigns. From the results in Table 4, it is clear that the high moisture content of the sludge/straw mix fuel, and the related low pyrolysis temperatures, have a pronounced effect on the total tar and water content in the product gas. The temperatures in the middle and upper part of the pyrolysis reactor, where the sludge pyrolysis takes place were around $650-700{ }^{\circ} \mathrm{C}$ in the REF and SLU campaigns, while it was $500-550{ }^{\circ} \mathrm{C}$ in the MIX-ST campaign. Pyrolysis temperatures around $500-550{ }^{\circ} \mathrm{C}$, have previously been reported as optimum temperatures for pyrolysis oil production from fast pyrolysis of sewage sludge and straw (Alvarez et al., 2015; Xie et al., 2014; Xin-bin et al., 2012). The pyrolysis process taking place in the LT-CFB occurs rapidly, as the heat transfer from the hot sand to the biomass or sludge, is extremely high. In general, such high heating rates combined with pyrolysis temperatures around $500-550{ }^{\circ} \mathrm{C}$ and short vapor residence times are regarded as beneficial conversion characteristics for pyrolysis oil production (Bridgwater et al., 1999). This supports the finding of very high tar content in the product gas from the MIX-ST campaign. If the tar characteristics can be optimized, then this system might be highly suitable for production of bio-oil from co-gasification of dewatered MSS and dry straw. The effective heating rate could be further increased and an even higher tar production probably be seen if the fuel was applied as finer and more dry particles.

GC-MS chromatograms (example in Figure 8) indicate that oxygenated compounds and phenols are the main constituents of the characterized tars from the REF campaign while a significantly different pattern was observed in the MIX-ST campaign: besides the phenols, a high amount of anhydro-carbohydrates such as levoglucosan appeared. This shows a good correlation with the higher water content of the straw-sludge mixture as well as the low pyrolysis temperature. The tar compounds in the MIX-ST gas were found to largely resemble a bio-oil composition considering the appearance of anhydrosugars, acetic acid, furfural and several phenols with a lower amount of PAHs (Trinh et al., 2013). Tars from the SLU-BJ campaign on the other hand clearly indicate that the fuel had a higher $\mathrm{N}$-content than that of straw or straw-sewage sludge mixtures. High amounts of $\mathrm{N}$-containing heterocyclic compounds were clearly present including pyrrole and indole and their methyl derivatives. Very similar compounds were found during gasification of Danish sewage sludge by Adegoroye et al. (Adegoroye et al., 2004). In another study by Zuo et al. sewage sludge was pyrolyzed in a 
fluidized bed reactor and the formation of nitrogenated compounds was studied with special focus on heterocyclic compounds. In this study a significant presence of pyrrole and also pyridine derivatives were also identified (Zuo et al., 2013).

Based on these results, it seems to be characteristic for tars from sludge gasification that they contain more $\mathrm{PAHs}$ and a lot of $\mathrm{N}$-heterocyclic compounds compared to the reference straw tar. During co-gasification of dewatered sludge and straw at the assessed mixing ratio, the resulting tars seem to be very similar to the regular straw gasification tars and have bio-oil like characteristics.

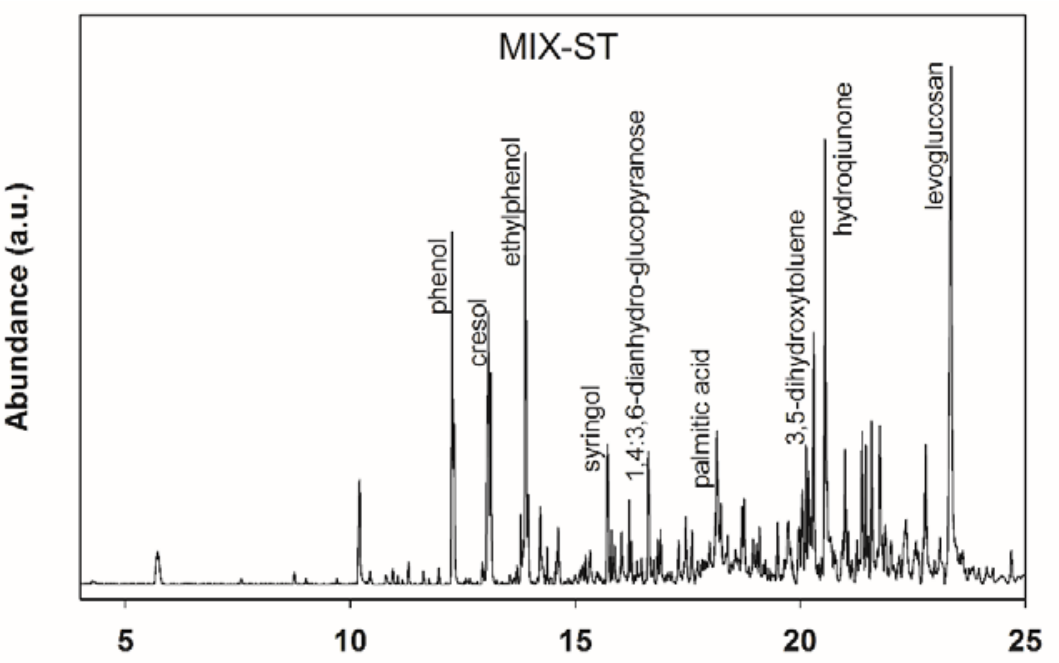

Figure 8: Example of GC-MS chromatogram of the tar fractions from the MIX-ST campaign.

\subsection{3 $\quad \mathrm{NH}_{3}$ and total $\mathrm{N}$ in gas product}

$2.1 \mathrm{~g}$ total $\mathrm{N}$ and $2.0 \mathrm{~g} \mathrm{NH}_{3}-\mathrm{N}$ was recovered per $\mathrm{Nm}^{3}$ of dry gas in the REF campaign while the recovery was only $0.07 \mathrm{~g}$ total- $\mathrm{N}$ and $0.06 \mathrm{~g} \mathrm{NH}_{3}-\mathrm{N}_{\text {per }} \mathrm{m}^{3}$ of dry gas in the MIX-ST campaign. The concentration of total $\mathrm{N}$ and $\mathrm{NH}_{3}-\mathrm{N}$ was thereby around a factor of 30 higher in the REF product gas than in the MIX-ST product gas. The large difference becomes even more profound when considering that the content of fuel $\mathrm{N}$ has been found to be a factor of 6 higher in MSS than in wheat straw on average across more than 40 samples measured per dry mass (ECN, 2016a, 2016b). The very large differences between the two sets of results are probably related to differences in allocation of $\mathrm{N}$ in the gas between tar- $\mathrm{N}, \mathrm{NH}_{3}, \mathrm{HCN}$ and $\mathrm{N}_{2}$ in the two campaigns. While all tar and tar- $\mathrm{N}$ species as well as $\mathrm{NH}_{3}$ is expected to condense in the impinger bottles, none of the produced $\mathrm{N}_{2}$ will be captured, and the contribution of HCN-N to total-N results is most likely severely underestimated as the bobble-flask approach may be inadequate of recovering $\mathrm{HCN}$ due to a very low boiling point (around $26^{\circ} \mathrm{C}$ ).

It is generally agreed, that the vast majority of fuel- $\mathrm{N}$ in gas from sludge pyrolysis is in the form of $\mathrm{NH}_{3}, \mathrm{HCN}$ and tar-bound N (Cao et al., 2010; Zhang et al., 2014). The production of $\mathrm{NO}_{x}$ in MSS pyrolysis has been found to be very low $\left(<0.5 \%\right.$ of fuel $\mathrm{N}$, (Tian et al., 2002)) but the $\mathrm{NH}_{3}, \mathrm{HCN}$ and tar-bound $\mathrm{N}$ are all potential precursors for post-pyrolysis $\mathrm{NO}_{x}$ formation in downstream gas combustion (Glarborg et al., 2003; Whitty et al., 2008). There are substantial differences in the distribution of fuel- $\mathrm{N}$, between $\mathrm{NH}_{3}$ and $\mathrm{HCN}$ while tar-bound $\mathrm{N}$ 
consequently represent around $1 / 3$ of total $\mathrm{N}$ in four studies of MSS pyrolysis (Cao et al., 2010; Chen et al., 2011; Tian et al., 2002; Zhang et al., 2014). In two cases it is found that $\mathrm{NH}_{3}$ constituted significantly more $\mathrm{N}$ than HCN (Cao et al., 2010; Zhang et al., 2014) where the exact opposite was the case in the other two studies (Chen et al., 2011; Tian et al., 2002). Two of the studies also found a significant content of $\mathrm{N}_{2}$ in the product gas, constituting $2-18 \%$ of fuel $N$ depending on the pyrolysis process (Cao et al., 2010; Chen et al., 2011). The formation of $\mathrm{N}_{2}$ in MSS pyrolysis has been found to rely on high temperature decomposition of $\mathrm{NH}_{3}$ as well as catalytic effects of iron-containing minerals, quartz and recalcitrant carbon (Chen et al., 2011; Tsubouchi and Ohtsuka, 2008). In a study by Mura et al (2013) it was found that the formation of $\mathrm{NO}_{\mathrm{x}}$ from combustion of $\mathrm{NH}_{3}$ rich gas from MSS pyrolysis was very limited at combustion temperatures up to $950^{\circ} \mathrm{C}$. Only $7 \%$ of the total $\mathrm{N}$ in the MSS pyrolysis gas was emitted in the exhaust as $\mathrm{NO}_{x}$ at air excess ratios of 1.1. This increased with more than a factor of 3 when the air excess ratio was increased from 1.1 to 2.3. The remaining $N$ was present in the exhaust gas predominately as $\mathrm{N}_{2}$. Mura et al proposed a spontaneous selective non-catalytic reduction reaction (SNCR) as the main driver for the low $\mathrm{NO}_{x}$ content in the exhaust (Mura et al., 2013).

From this assessment it seems as there is a substantial potential for production of $\mathrm{NO}_{\mathrm{x}}$-precursors during thermal gasification of MSS based fuels, but also that the practical implications of this concern may become small if the pyrolysis/gasification and gas combustion processes are optimized in this regard.

\subsection{Process performance}

\subsubsection{Overall energy balance and energy efficiency}

As the LT-CFB product gas is mainly intended for being combusted without prior cooling it makes sense to regard the hot-gas efficiency of the process. This is estimated from an energy based distribution of products and results are provided in Table 5.

Table 5: Carbon conversion rates and allocation of fuel energy potential in products and unaccounted fractions during selected Low Temperature Fluidized Bed gasification campaigns. SC: Secondary cyclone.

\begin{tabular}{lcccccc}
\hline & $\begin{array}{c}\text { SC ash } \\
\text { carbon }\end{array}$ & $\begin{array}{c}\text { Filter ash } \\
\text { carbon }\end{array}$ & $\begin{array}{c}\text { Bed carbon } \\
\text { (incl. drained) }\end{array}$ & $\begin{array}{c}\text { Hot gas } \\
\text { (efficiency) }\end{array}$ & $\begin{array}{c}\text { Unaccounted } \\
\text { (balance) }\end{array}$ & $\begin{array}{c}\text { Carbon } \\
\text { conversion }\end{array}$ \\
\hline MJ/MJ fuel & MJ/MJ fuel & MJ/MJ fuel & MJ/MJ fuel & MJ/MJ fuel & $\%$ \\
\hline MIX-ST & 0.06 & 0.03 & 0.02 & 0.82 & 0.07 & $86^{\mathrm{b}}$ \\
MIX-BJ & 0.04 & N.A. & 0.00 & 0.90 & 0.06 & $95^{\mathrm{b}}$ \\
SLU-BJ $^{\mathrm{a}}$ & 0.08 & N.A. & 0.01 & 0.88 & 0.04 & $91^{\mathrm{b}}$ \\
\hline
\end{tabular}

The unaccounted fraction of the fuel energy input (Table 5) includes i.e. surface heat loss not fully compensated by electric surface heat tracing, loss of thermal enthalpy in ash products, enthalpy losses in phase changes (in addition to that of water) and the sum is finally influenced by substantial uncertainties in all parameters. SC ash carbon content is found to constitute $2-8 \%$ of the original fuel energy and seems to increase with straw content. Combined with the filter ash carbon and the carbon in the bed material, these 
losses account for a total of approximately $5-10 \%$ of the fuel energy. Carbon conversion rates on basis of total carbon mass in the fuels were in the range $85-95 \%$ and increase in processes with high ash or moisture levels in the fuels which is mainly due to the need for higher air to fuel ratio and therefor more oxidising conditions in the char reactor. Carbon conversion rates from $48-85 \%$ were obtained in a study by Seggiani et al. on cogasification of MSS and wood while carbon conversion rates of $65-93 \%$ were obtained in four recent studies on mono-gasification of MSS in various types of gasifiers (Choi et al., 2016; Kang et al., 2011; Mun et al., 2013; Roche et al., 2014; M. Seggiani et al., 2012). The estimated hot-gas efficiencies in the MSS campaigns were around $88-90 \%$ and highest in the MIX-ST campaign. The efficiency of the LT-CFB MSS process is in the high end regardless of the MSS fuel composition when compared to the previously published literature on MSS gasification. Hot gas efficiencies of $40-70 \%$ and cold gas efficiencies from $30-89 \%$ have been stated in a series of previous studies on MSS gasification involving several different types of gasifiers (Calvo et al., 2013; Choi et al., 2016; Kang et al., 2011; Mun et al., 2013; Werle, 2015).

\section{Conclusions}

Process performance and gas product quality and quantity have been compared across five successful experimental Low Temperature Circulating Fluidized Bed (LT-CFB) campaigns operated on different fuels and LT-CFB plants. Four of the fuels were municipal sewage sludge (MSS) or a mix of MSS and cereal straw. The fifth fuel was a reference cereal straw fuel. No bed agglomeration or ash sintering was observed in the assessed temperature regime. Regardless of substantial differences in the hot gas composition and tar content of the gas products from the different LT-CFB campaigns, hot gas energy efficiencies close to $90 \%$ and carbon conversion rates in the range of 90-95\% were documented in all assessed cases with MSS fuels or fuel mixes.

Many other gasification concepts have also been tested successfully on MSS fuels, but in general fluidized bed based gasifiers obtains the highest thermal efficiencies. Among these highly efficient systems, the LT-CFB has a distinct characteristic in the very low operation temperature which allows for mixing the MSS with straw and other high alkali biomass residues. This approach can be used to mitigate two common problems with MSS gasification in fluidized bed systems; i) MSS gasification can lead to accumulation of large amounts of inorganic material from the fuel in the bed, requiring extensive extraction of bed material and in some cases addition of fresh bed material to allow for continuous operation. However, co-gasification of MSS with straw was found to be an effective way to mitigate this issue; ii) Co-gasification of dewatered MSS and straw seems to be sufficient to avoid the expense of thermal drying of MSS prior to thermal gasification.

When mixing wet or dewatered MSS with straw, the relatively high moisture content of the mixed fuel did have an expectable influence on the process conditions, especially in the pyrolysis reactor. A very high tar production was documented in this campaign, owing mainly to low temperatures in the pyrolysis reactor. Characterization of the tar has indicated a potential use as a liquid fuel (bio-oil) if condensed and separated from the product gas. With further investigation this could increase the process flexibility by expanding the potential product range. 
The overall conclusion of this study is that LT-CFB gasification of MSS and especially co-gasification of MSS and cereal straw is a highly efficient way to manage MSS and utilize the energy potential in this resource. The low temperature gasifier can convert MSS or MSS/straw mixtures into a combustible and/or condensable product gas, and the product gas characteristics can be altered substantially by changing the fuel composition.

The prospect of utilizing the ashes produced in the described LT-CFB campaigns as phosphorus fertilizer and soil improvement agents is the subject of part 2 of the current study.

\section{References}

Adegoroye, A., Paterson, N., Li, X., Morgan, T., Herod, A.A., Dugwell, D.R., Kandiyoti, R., 2004. The characterisation of tars produced during the gasification of sewage sludge in a spouted bed reactor. Fuel 83, 1949-1960. doi:10.1016/j.fuel.2004.04.006

Ahrenfeldt, J., Thomsen, T.P., Henriksen, U., Clausen, L.R., 2013. Biomass gasification cogeneration - A review of state of the art technology and near future perspectives. Appl. Therm. Eng. 50, 1407-1417. doi:10.1016/j.applthermaleng.2011.12.040

Alvarez, J., Amutio, M., Lopez, G., Barbarias, I., Bilbao, J., Olazar, M., 2015. Sewage sludge valorization by flash pyrolysis in a conical spouted bed reactor. Chem. Eng. J. 273, 173-183. doi:10.1016/j.cej.2015.03.047

Arjharn, W., Hinsui, T., Liplap, P., Raghavan, G.S.V., 2013. Evaluation of an Energy Production System from Sewage Sludge Using a Pilot-Scale Downdraft Gasifier. Energy \& Fuels 27, 229-236.

Bridgwater, A. V., Meier, D., Radlein, D., 1999. An overview of fast pyrolysis of biomass. Org. Geochem. 30, 1479-1493.

Buchholz, D., 2015. Gasifying sludge and slurry: Europe's circular economy in action. Renew. Energy Focus 16, 147-149. doi:10.1016/j.ref.2015.10.019

Calvo, L.F., García, A.I., Otero, M., 2013. An Experimental Investigation of Sewage Sludge Gasification in a Fluidized Bed Reactor. Sci. World J. 2013, 1-8.

Cao, J.-P., Li, L.-Y., Morishita, K., Xiao, X.-B., Zhao, X.-Y., Wei, X.-Y., Takarada, T., 2010. Nitrogen transformations during fast pyrolysis of sewage sludge. Fuel 104, 1-6. doi:10.1016/j.fuel.2010.08.015

Chang, R., College, W., 2002. Chemistry, 7th ed. McGraw Hill, New York, NY.

Chen, H., Namioka, T., Yoshikawa, K., 2011. Characteristics of tar, NOx precursors and their absorption performance with different scrubbing solvents during the pyrolysis of sewage sludge. Appl. Energy 88 , 5032-5041. doi:10.1016/j.apenergy.2011.07.007

Choi, Y.-K., Mun, T.-Y., Cho, M.-H., Kim, J.-S., 2016. Gasification of dried sewage sludge in a newly developed three-stage gasifier: Effect of each reactor temperature on the producer gas composition and impurity removal. Energy 114, 121-128. doi:10.1016/j.energy.2016.07.166 
Cordell, D., White, S., 2014. Life's Bottleneck: Sustaining the World's Phosphorus for a Food Secure Future. Annu. Rev. Environ. Resour. Vol 39 39, 161-188. doi:DOI 10.1146/annurev-environ-010213-113300

DanSand.dk, 2013. SIEVE ANALYSIS Sand 13 [WWW Document]. DanSand. URL http://www.dansand.dk/fileadmin/content/DATABLADE_PDF/S_V_13.eng.pdf (accessed 7.25.16).

Donatello, S., Cheeseman, C.R., 2013. Recycling and recovery routes for incinerated sewage sludge ash (ISSA): A review. Waste Manag. 33, 2328-2340. doi:10.1016/j.wasman.2013.05.024

DONG Energy Power A/S, 2012. Pyroneer, A new Gasolution - Biomass gasification [WWW Document]. URL http://www.pyroneer.com/en (accessed 9.23.16).

ECN, 2016a. Phyllis2 - Database for biomass and waste [WWW Document]. URL https://www.ecn.nl/phyllis2/Browse/Standard/ECN-Phyllis\#sewage sludge (accessed 8.16.16).

ECN, 2016b. Phyllis2 - Database for biomass and waste [WWW Document]. URL https://www.ecn.nl/phyllis2/Browse/Standard/ECN-Phyllis\#wheat straw (accessed 8.16.16).

Engineeringtoolbox.com, 2016a. The Engineering ToolBox - Solids - Specific Heats [WWW Document]. URL http://www.engineeringtoolbox.com/specific-heat-solids-d_154.html (accessed 10.14.16).

Engineeringtoolbox.com, 2016b. The Engineering ToolBox - Nitrogen - Specific Heat [WWW Document]. URL http://www.engineeringtoolbox.com/nitrogen-d_977.html (accessed 10.4.16).

Engineeringtoolbox.com, 2016c. The Engineering ToolBox - Carbon Dioxide Gas - Specific Heat [WWW Document]. URL http://www.engineeringtoolbox.com/carbon-dioxide-d_974.html (accessed 10.4.16).

Engineeringtoolbox.com, 2016d. The Engineering ToolBox - Water Vapor - Specific Heat [WWW Document]. URL http://www.engineeringtoolbox.com/water-vapor-d_979.html (accessed 10.4.16).

Fonts, I., Gea, G., Azuara, M., Ábrego, J., Arauzo, J., 2012. Sewage sludge pyrolysis for liquid production: A review. Renew. Sustain. Energy Rev. 16, 2781-2805. doi:10.1016/j.rser.2012.02.070

Fytili, D., Zabaniotou, A., 2008. Utilization of sewage sludge in EU application of old and new methods-A review. Renew. Sustain. Energy Rev. 12, 116-140. doi:10.1016/j.rser.2006.05.014

Glarborg, P., Jensen, A.D., Johnsson, J.E., 2003. Fuel nitrogen conversion in solid fuel fired systems. Prog. Energy Combust. Sci. 29, 89-113. doi:10.1016/S0360-1285(02)00031-X

Grosch, H., Sárossy, Z., Egsgaard, H., Fateev, A., 2015. UV absorption cross-sections of phenol and naphthalene at temperatures up to $500^{\circ} \mathrm{C}$. J. Quant. Spectrosc. Radiat. Transf. 156, 17-23.

Hansen, V., Hauggaard-Nielsen, H., Petersen, C.T., Mikkelsen, T.N., Müller-Stöver, D., 2016. Effects of gasification biochar on plant-available water capacity and plant growth in two contrasting soil types. Soil Tillage Res. 161, 1-9. doi:10.1016/j.still.2016.03.002

Hansen, V., Müller-Stöver, D., Ahrenfeldt, J., Holm, J.K., Henriksen, U.B., Hauggaard-Nielsen, H., 2015. Gasification biochar as a valuable by-product for carbon sequestration and soil amendment. Biomass Bioeng. 72, 300-308. doi:10.1016/j.biombioe.2014.10.013 
Jenkins, R.G., 2015. Thermal Gasification of Biomass - A Primer. Bioenergy Biomass to biofuels 261-286. doi:10.1016/B978-0-12-407909-0.00016-X

Judex, J.W., Gaiffi, M., Burgbacher, H.C., 2012. Gasification of dried sewage sludge: Status of the demonstration and the pilot plant. Waste Manag. 32, 719-723. doi:10.1016/j.wasman.2011.12.023

Kang, S.W., Dong, J.I., Kim, J.M., Lee, W.C., Hwang, W.G., 2011. Gasification and its emission characteristics for dried sewage sludge utilizing a fluidized bed gasifier. J. Mater. Cycles Waste Manag. 13, 180-185. doi:10.1007/s10163-011-0016-y

Kelessidis, A., Stasinakis, A.S., 2012. Comparative study of the methods used for treatment and final disposal of sewage sludge in European countries. Waste Manag. 32, 1186-1195. doi:10.1016/j.wasman.2012.01.012

Krüger, O., Adam, C., 2015. Recovery potential of German sewage sludge ash. Waste Manag. Urban Mini, 400406. doi:10.1016/j.wasman.2015.01.025

Krüger, O., Grabner, A., Adam, C., 2014. Complete Survey of German Sewage Sludge Ash. Environ. Sci. Technol. $48,11811-11818$.

Kuligowski, K., Poulsen, T.G., Stoholm, P., Pind, N., Laursen, J., 2008. Nutrients and heavy metals distribution in thermally treated pig manure. Waste Manag. Res. 26, 347-354. doi:10.1177/0734242X08090075

Kunii, D., Levenspiel, O., 1991. Fluidization Engineering, Second. ed. Butterworth-Heinemann, Newton.

Mun, T.Y., Kim, J.S., 2013. Air gasification of dried sewage sludge in a two-stage gasifier. Part 2: Calcined dolomite as a bed material and effect of moisture content of dried sewage sludge for the hydrogen production and tar removal. Int. J. Hydrogen Energy 38, 5235-5242. doi:10.1016/j.ijhydene.2013.02.073

Mun, T.Y., Kim, J.W., Kim, J.S., 2013. Air gasification of dried sewage sludge in a two-stage gasifier: Part 1. the effects and reusability of additives on the removal of tar and hydrogen production. Int. J. Hydrogen Energy 38, 5226-5234. doi:10.1016/j.ijhydene.2012.10.120

Mura, E., Debono, O., Villot, A., Paviet, F., 2013. Pyrolysis of biomass in a semi-industrial scale reactor: Study of the fuel-nitrogen oxidation during combustion of volatiles. Biomass Bioeng. 59, 187-194. doi:10.1016/j.biombioe.2013.09.001

Narayan, V., Jensen, P.A., Henriksen, U.B., Egsgaard, H., Nielsen, R.G., Glarborg, P., 2016. Behavior of Alkali Metals and Ash in a Low-Temperature Circulating Fluidized Bed (LTCFB) Gasifier. Energy and Fuels 30, 1050-1061. doi:10.1021/acs.energyfuels.5b02464

Nielsen, R.G., 2007. Optimering af Lav Temperatur Cirkulerende Fluid Bed forgasningsprocessen til biomasse med højt askeindhold (Eng.: Optimizing Low Temperature Circulating Fluidized Bed gasification for high alkali biomass). Technical University of Denmark, Lyngby, Denmark.

Ong, Z., Cheng, Y., Maneerung, T., Yao, Z., Tong, Y.W., Wang, C.-H., Dai, Y., 2015. Co-gasification of woody biomass and sewage sludge in a fixed-bed downdraft gasifier. AIChE J. 61, 2508-2521. doi:10.1002/aic.14836

Roche, E., De Andrés, J.M., Narros, A., Rodríguez, M.E., 2014. Air and air-steam gasification of sewage sludge. 
The influence of dolomite and throughput in tar production and composition. Fuel 115, 54-61. doi:10.1016/j.fuel.2013.07.003

Samolada, M.C., Zabaniotou, A.A., 2014. Comparative assessment of municipal sewage sludge incineration, gasification and pyrolysis for a sustainable sludge-to-energy management in Greece. Waste Manag. 34, 411-420. doi:10.1016/j.wasman.2013.11.003

Seggiani, M., Puccini, M., Raggio, G., Vitolo, S., 2012. Effect of sewage sludge content on gas quality and solid residues produced by cogasification in an updraft gasifier. Waste Manag. 32, 1826-1834. doi:10.1016/j.wasman.2012.04.018

Seggiani, M., Vitolo, S., Puccini, M., Bellini, A., 2012. Cogasification of sewage sludge in an updraft gasifier. Fuel 93, 486-491. doi:10.1016/j.fuel.2011.08.054

Stoholm, P., Ahrenfeldt, J., Henriksen, U., Gómez, A., Krogh, J., Nielsen, R.G., Sander, B., 2008. The Low Temperature CFB Gasifier - 500 kW test on Biogas Fiber Residue, in: 16th European Biomass Conference \& Exhibition, 2-6 June 2008, Valencia, Spain. pp. 720-723.

Thomsen, T.P., Hauggaard-Nielsen, H., Gøbel, B., Stoholm, P., Ahrenfeldt, J., Henriksen, U.B., Müller-Stöver, D.S., 2017. Low Temperature Circulating Fluidized Bed gasification and co-gasification of Municipal Sewage Sludge. Part 2: Evaluation of ash materials as phosphorus fertilizer. Waste Manag. In Press.

Thomsen, T.P., Ravenni, G., Holm, J.K., Ahrenfeldt, J., Hauggaard-Nielsen, H., Henriksen, U.B., 2015. Screening of various low-grade biomass materials for low temperature gasification: Method development and application. Biomass Bioeng. 79, 128-144. doi:10.1016/j.biombioe.2014.12.019

Tian, F.J., Li, B.Q., Chen, Y., Li, C.Z., 2002. Formation of NOx precursors during the pyrolysis of coal and biomass. Part V - Pyrolysis of a sewage sludge. Fuel 81, 2203-2208. doi:10.1016/S0016-2361(02)00139-4

Trinh, T.N., Jensen, P.A., Sárossy, Z., Dam-Johansen, K., Knudsen, N.O., Sørensen, H.R., Egsgaard, H., 2013. Fast pyrolysis of lignin using a pyrolysis centrifuge reactor. Energy and Fuels 27, 3802-3810. doi:10.1021/ef400527k

Tsubouchi, N., Ohtsuka, Y., 2008. Nitrogen chemistry in coal pyrolysis: Catalytic roles of metal cations in secondary reactions of volatile nitrogen and char nitrogen. Fuel Process. Technol. 89, 379-390. doi:10.1016/j.fuproc.2007.11.011

Turns, S.R., 2012. An Introduction to Combustion - Concepts and Applications, Third. ed. McGraw-Hill, New York, NY.

Werle, S., 2015. Gasification of a Dried Sewage Sludge in a Laboratory Scale Fixed Bed Reactor. Energies 8 , 8562-8572. doi:10.3390/en8088562

Whitty, K.J., Zhang, H.R., Eddings, E.G., 2008. Emissions from Syngas Combustion. Combust. Sci. Technol. 180, 1117-1136. doi:10.1080/00102200801963326

Xiaoxu, F., Leizhe, C., Liguo, Y., 2012. Dried Municiple Sewage Sludge Gasification Experiment in Dual Fluidized Bed. Adv. Mater. Res. 390, 3799-3804. doi:10.4028/www.scientific.net/AMR.383-390.3799 
Xie, Q., Peng, P., Liu, S., Min, M., Cheng, Y., Wan, Y., Li, Y., Lin, X., Liu, Y., Chen, P., Ruan, R., 2014. Fast microwave-assisted catalytic pyrolysis of sewage sludge for bio-oil production. Bioresour. Technol. 172, 162-168. doi:10.1016/j.biortech.2014.09.006

Xin-bin, Z., Jian-guo, H., Yong-xiang, Z., Wei-ming, S., 2012. Genotypic variation of rape in phosphorus uptake from sparingly soluble phosphate and its active mechanism. African J. Biotechnol. 11, 3061-3069. doi:10.5897/AJB11.3043

Zhang, J., Tian, Y., Zhu, J., Zuo, W., Yin, L., 2014. Characterization of nitrogen transformation during microwaveinduced pyrolysis of sewage sludge. J. Anal. Appl. Pyrolysis 105, 335-341. doi:10.1016/j.jaap.2013.11.021

Zsirai, I., 2011. Sewage Sludge as Renewable Energy. J. Residuals Sci. Technol. 8, 165-179.

Zuo, W., Jin, B., Huang, Y., Sun, Y., Li, R., Jia, J., 2013. Pyrolysis of high-ash sewage sludge in a circulating fluidized bed reactor for production of liquids rich in heterocyclic nitrogenated compounds. Bioresour. Technol. 127, 44-48. doi:10.1016/j.biortech.2012.09.017 